\title{
Three Urbanisms in One City: Accommodating the Paces of Change
}

\author{
Rob Roggema \\ VHL University of Applied Sciences, Velp, The Netherlands \\ Email: rob@cittaideale.eu, rob.roggema@wur.nl
}

Received 17 July 2015; accepted 30 August 2015; published 2 September 2015

Copyright (C) 2015 by author and Scientific Research Publishing Inc.

This work is licensed under the Creative Commons Attribution International License (CC BY).

http://creativecommons.org/licenses/by/4.0/

(c) (i) Open Access

\begin{abstract}
In current times urban developments can no longer be seen as straightforward building of the required number of houses, industries and parking spaces. Instead, the problems in many cities are of different nature: urban conurbations may shrink, or climate impacts cause a serious disaster. These problems all have a different pace of development. The fast development must be combined with slower development pace fitting with shrinking cities and the sudden change climatic impacts requires. Therefore, in this article three types of urbanisms are proposed, which each care for an increase of resilience in the city. Fast urbanism accommodates the growth of the city in a calculated way in periods of economic prosperity; slow urbanism designs spaces for slowly developing uses such as ecology or food in times of shrinkage; and suddenism anticipates future climate impacts through designing spaces for temporary use.
\end{abstract}

\section{Keywords}

Urbanism, Slow Urbanism, Fast Urbanism, Suddenism, Resilience, Climate Impacts, Shrinking City

\section{Introduction}

The way we plan our cities is generally driven by two straightforward factors. There is economic growth and accordingly urban growth or the population increases, also leading to increasing demand for urban space. These two factors are often intermingled. However, recently other phenomena have been influencing the city, such as a shrinking population or climate impacts and disasters. These aspects are difficult, or at least unusual, in the urban planning process, because they have a fundamental different pace of change than the good old housing or industrial development tasks. Therefore, in this article two new types of urbanism are introduced: slow urbanism and suddenism, which are capable of accommodating faster of slower change in the city. 


\section{Background}

The UN estimates that $66 \%$ of the world population in 2050 lives in cities [1]. People are on the move (Figure 1 ) towards, in their opinions, the best urban places. Their migration has several causes: hunger, climate threat or safety. Besides the birth rate, which can be qualified as a natural cause of population growth, economic, humanitarian and safety factors determine migration.

In many urban areas around the world population explosion requires a quick response. Asian, African and South American metropolises are growing so rapidly that the government has trouble planning sufficient housing areas. This leads to quick developed new towns on the one hand side and slums and informal precincts on the other. Planning cities under rapidly changing circumstances can hardly be undertaken without parts developing informal and uncontrolled. Some of the effects of these developments is higher crime rates, hunger and safety problems. The flipside is these insurgent developments show the energy and power of self-organisation. When governments take control over planning system this power is also reduced. The question asked if a city

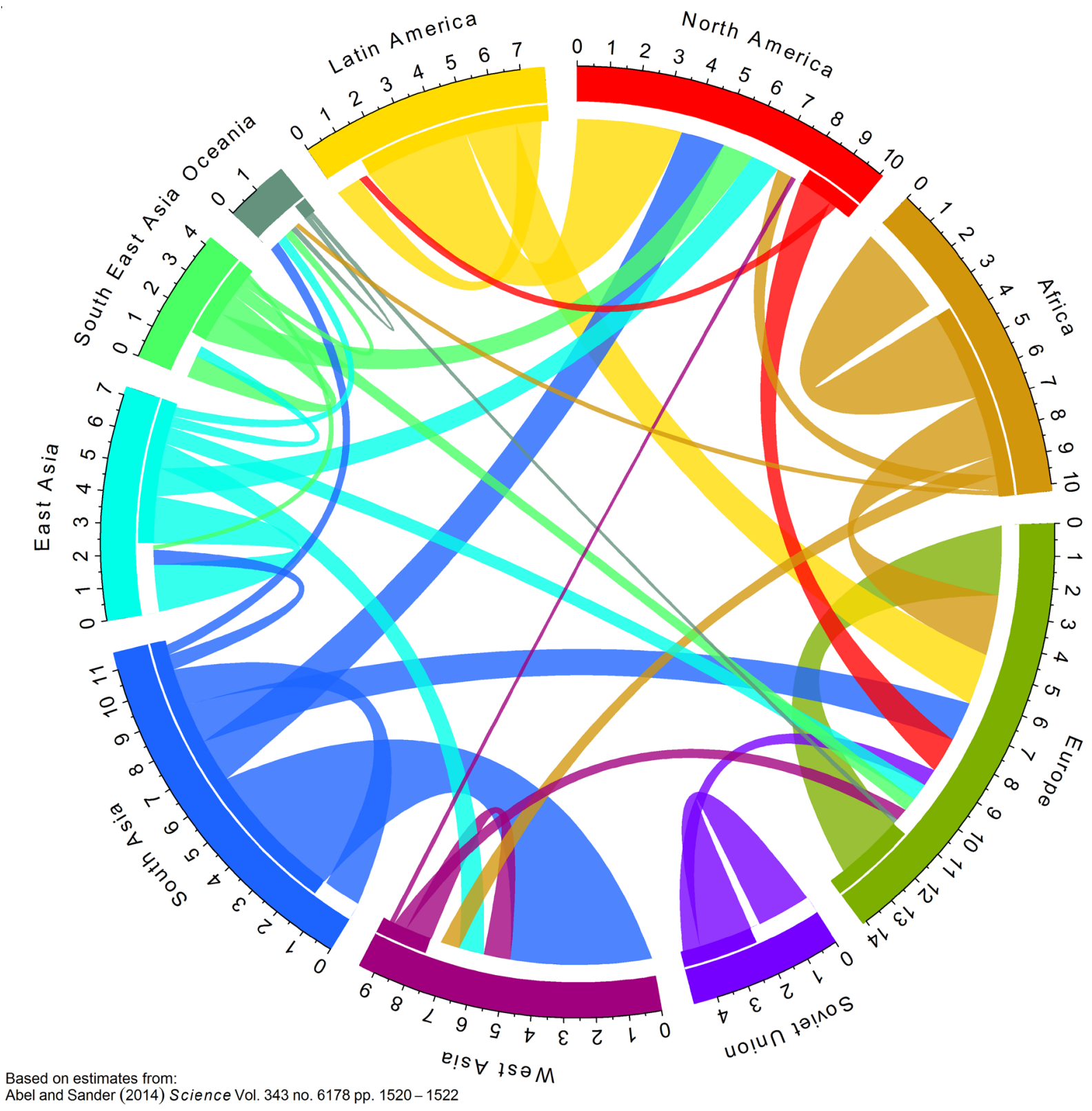

Figure 1. Global migration flows [2]. Based on [3] [4]. 
could use its self-organising strengths to plan for a rapidly increasing population in a sustainable (sufficient renewable energy, clean and recycled water, healthy, local food) and safe (low crime) way?

Secondly, climate change is expected to increase the number of sudden, unprecedented and uncertain events [5]. Especially cities are vulnerable, as they are lacking space to accommodate a disaster, but also because many are planned in areas vulnerable for the impacts such as coastal flooding and storm surges, bushfires and heat [6]-[9].

A third development is the shrinkage of cities in some parts of the world, such as North America and Europe [10]-[17]. In many cases shrinkage led to detoriated precincts, abandoned areas, empty buildings and rundown public spaces. This gave reason to many of the city governments to develop planning policies how to deal with those problems [18]-[22] and sketch a positive perspective, such as for Detroit [23], Limburg [24], Groningen East [25] and East Germany [26] [27]. At the same time an uprise of social connectivity and self-organisation of population collectives is visible. Increasingly, residents are organising themselves in cooperatives to share the care for their direct environment [28]-[31]. Examples of these cooperatives can be found in Kloosterburen [32], in the Pop-up city of Cleveland [33], or in Dessau [34]. The cooperatives can take shape as energy collectives [35]-[39], in urban agriculture [40]-[43], and in care [44]-[46].

\section{Problem Definition}

The city is confronted with the divergent trends as sketched above. It needs to deal with rapid growth of population, severe impacts of climate change and shrinkage of the city all at the same time. Currently the modus operandi of many city planners is to accommodate the growth of the city only, leaving the impacts of climate change and shrinkage aside as "difficult to plan for". Cities need to cater for all three developments at the same time, no matter how far the developments seem to lay apart. The problems of current cities around the world are that they face an explosive population growth, or they shrink, they are vulnerable for impacts of climate change such as floods, fires, hurricanes and sandstorms, and at the same time the regeneration of plants, water, the ecological system requires time. To accommodate these problems and turn them around in sustainable and prosperous cities, a diversity of resilience is essential for these cities.

\section{Resilience and Planning}

Resilience is defined as "the capacity of a system to absorb disturbance and reorganize while undergoing change so as to still retain essentially the same function, structure, identity and feedbacks" [47] [48]. It includes the ability to learn from disturbance (Post Carbon Institute, undated). A core question of resilience theory is how resilience in a system could be increased. In the context of this article, urban systems are socio-ecological systems. The theoretical framework relating to resilience [48] and resilient cities [49] focuses strongly on the mechanics of the system or the city, but to date, this has not resulted in more resilient cities. Concrete, practical directions on how to build a resilient city are often lacking, even when the metabolism of the city is known in detail [50]. Resilience is also known as adaptive capacity. It is one of three properties of the so-called adaptive cycle and is defined as "a measure of its vulnerability to unexpected or unpredictable shocks. [Alternatively, it] can be thought of as the opposite of the vulnerability of the system" [51]. The adaptive cycle alternates between long periods of aggregation and transformation of resources, followed by shorter periods of uncertainty that create opportunities for innovation. It is proposed by some as a fundamental tool for understanding complex systems, from cells to ecosystems, and to societies. Ecosystem and social-ecological system dynamics can be represented by an adaptive cycle with two major phases. The first, often referred to as the fore-loop, is defined by a shift from growth or exploitation (r) to conservation (K). It is the slow, incremental phase of growth and accumulation. The second phase, referred to as the back-loop, is defined by a shift from collapse $(\Omega)$ to reorganisation $(\alpha)$. This is the rapid phase of reorganisation leading to renewal [52]. The $\alpha$-phase is especially important for the resilience of the system [51] and is especially important when a system needs to reconfigure during times of crisis or stress, such as might be expected by the impacts of climate change or disaster.

A more straightforward definition of resilience is "the capacity of a system to absorb disturbance and reorganise while undergoing change so as to still retain essentially the same function, structure, identity and feedbacks" [47] [48]. Importantly, this definition includes the ability to learn from disturbance [53]. Generally, resilience is seen as a property of socio-ecological systems, allowing the system to bounce back and recover from an external shock. Adaptability is the capacity of actors to influence resilience [47]. The collective capacity to 
manage resilience determines whether the actors can successfully avoid crossing into an undesirable system regime, or if necessary, to return to a desirable one. The question is, however if these principles can be applied to the design of a city? To a certain extent, the answer is yes. It is beneficial to include biodiversity, clean water and more inclusive social environments in city design. But do these features still function during a disaster, when risks become uncertain, or in the case of extreme climatic events [54] [55]?

Building resilience is essential in times of crisis. Ecosystems tend to enter a path of turbulent change when they are over-managed for stability [56], and the process seems to accelerate under stress. More to the point, if we keep focusing on the resilient city as an urban area with mechanical sustainability "features", the question may be raised if the city can adapt to future climate impacts and whether the city is really resilient at all. In light of the dangers of focusing on stability as a solution, a city might be better off if it were able to constantly change its shape under the influence of external shocks, able to relocate urban components when necessary. Such flexibility can be referred to as functioning like a swarm [57]. We probably don't know yet how to build these cities, however, some of our current knowledge offers hints. Such a city would need to increase its diversity and modularity, contain (tight) feedback sensitive structures [48], cited in [58] and include a certain amount of redundancy in terms of functions [59]. These properties would contribute to the resilience of the city, and highlight the potential flexibility and adaptability of (urban) built environments and communities. Redundancy provides the city with free space for new functions to emerge, diversity multiplies the differences in objects, allowing the city to transform in a modular way. Modularity, affords urban objects the ability to move and easily connect and disconnect from each other. Finally, tight feedback allows urban objects to mutually react to one another, developing self-organisation and optimizing its form according to change needs. These properties could be seen as a preliminary set of guiding principles for resilience planning.

In this context three relevant ways of design and planning are distinguished [60]-[62]: probable, possible and imaginable (Figure 2). "The difference between empirical research and technical design is, essentially, the difference between exploring what is probable and what is possible in the future. To look more closely at the difference between probable and possible futures before we descend into modal logic, we can conclude, quite simply, that anything probable is by definition possible, but not the reverse. This means, then, that there are improbable possibilities. The probable ones can be predicted and explored using the usual means of empirical research simply because they are probable. But how can we explore improbable possibilities? That is precisely the role of design. A designer imagines improbable possibilities that do not yet exist. If designs were probable, they would be predictions and not designs. Designs are not what is 'true' or 'probable', but what is 'imaginable' and 'possible"' [62].

When these perspectives on design are combined with the problems identified, rapid population growth and economic development is seen as business as usual. In normal circumstances the size of the population can be very well predicted and economic growth is calculated. This implies a probabilistic approach and in these contexts design can be characterised as "engineering"; for measurable problems quantifiable designs are developed. The urban systems derived in this era are strong and can be measured. In dealing with unexpected change the city braces itself, resisting the change and aims to defend its current status, structures and systems and to bounce back after an external impact has occurred.

A second perspective on design occurs when the city shrinks, or at least doesn't grow at a fast pace any more. Suddenly the tight measurements are loosened and there is space for other values than economic. This implies the city can look for (new) possibilities to feed the quality of urban systems; for new opportunities and uses that
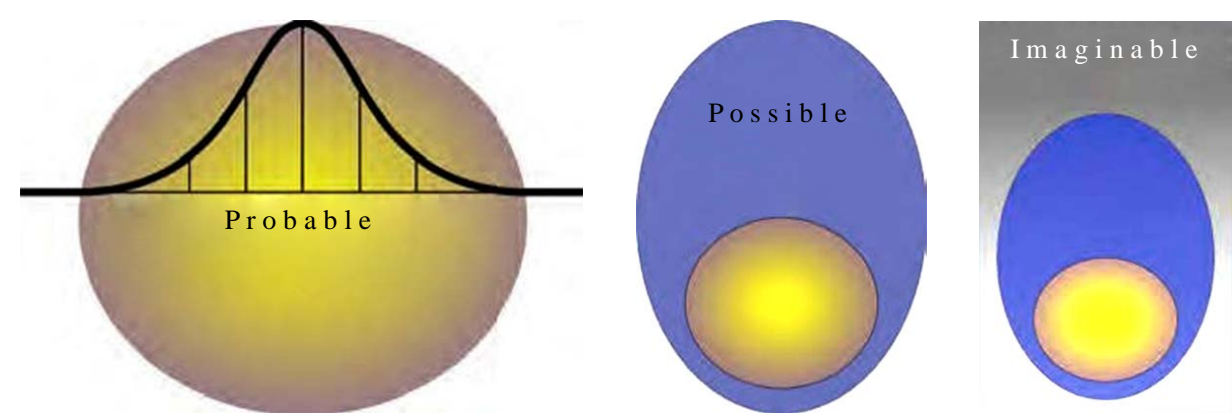

Figure 2. Probable, possible and imaginable [62]. 
are not primarily economically driven, such as industries and housing. In this context no engineering but imaginative design is needed, to shape the new possibilities. The urban systems in this context are flexible and offer space for uses that were moved out of the city when it grew. In times of unexpected change the city can easily respond as there are margins in the urban fabric that can be used to reorganise urban uses, structures and systems.

The third perspective on design, the imaginable, can be used when external climatic impacts suddenly occur. When unprecedented events take place the city needs to adjust itself, even if this doesn't seem possible. Space is required to for the impact of these events and often there is no space available. In order to accommodate this required space we enter the area of imagination; the city imagines spaces that seem not to be there when everything is normal and no disaster is happening. This way the city anticipates these events without exactly knowing which disasters to cater for. This adaptive design approach makes it possible for urban spaces and uses to change when there is a need, for instance a parking space or soccer field can turn into water storages in case of flooding.

These three design perspectives (engineering, design and anticipative design are linked with typical urban transformations (rapid growth, shrinkage and climate impacts) and can be combined with appropriate resilience strategies (resist, respond, anticipate).

\section{Three Urbanisms}

As mentioned before, the three design strategies (probabilistic, possibilities and imaginative) are used for different types of urban change.

The engineering approach can be used in case of rapid growth, design when the city shrinks and when the city is confronted with sudden climatic impacts adaptive design is preferable. Additionally, certain types of urban problems are better dealt with each of these strategies than others. Issues such as housing, the need for industrial area, and water or road traffic, can be easily calculated. Often the calculation determines the engineered design of the city in number of highway lanes and parking lots, the amount of dwellings or the hectares of industrial estate. Because these issues are at the front of urban design in times of economic prosperity and developments are fast, the chosen name for this type of urbanism is Fast Urbanism (see Table 1).

When the problems are of a less measurable nature, the "design" approach is useful. These land-uses, such as nature and ecology, food and urban agriculture, water as basis for ecology and culture, are uses, which are not economically driven. The size or amount of these uses is always seen as arbitrary and the area required in the city cannot be estimated in detail. This requires creation of new concepts for the urban fabric. The design of the city determines the quality and size of these uses, when the pressure to realise housing developments or industries decreases. Moreover, ecological development, food production and cultural heritage develop over longer periods and slowly. Therefore this type of urbanism is called Slow Urbanism (Table 1).

Adaptive design is necessary when the city if forced to adjust its spaces under climatic stresses. Problems aligned with this are sudden events such as floods, bushfires, earthquakes or tsunami's. The fact that many of these events are unprecedented makes them also unpredictable. Therefore, urban spaces need to adjust their use suddenly and for a short period of time. This temporary urban use requires spatial reservations, or intermittent use of the same urban space. The unpredictability makes the design process partly intuitive. The chosen name

\begin{tabular}{cccc}
\hline \multicolumn{2}{l}{ Table 1. Three urbanisms. } & & \\
\hline Design strategy & Probable & Possible & Imaginable \\
\hline Design approach & Engineering & Design & Adaptive design \\
Urban change & Rapid growth & Shrinkage & Climate impacts \\
Resilience type & Resist & Respond & Anticipate \\
Urbanism & Fast urbanism & Slow urbanism & Suddenism \\
& Housing & Ecology & Flood \\
Urban problems & Economic growth & Food/urban agriculture & Fire \\
& Traffic (water) & Water for nature & Earthquake \\
Type of action & Culture & Tsunami \\
& Calculation & Creation & Intuition \\
\hline
\end{tabular}


for this type urbanism, accommodating these temporary uses, is Suddenism (Table 1).

\subsection{Fast Urbanism}

The term fast urbanism is not very common in literature. It is seen as the spatial experience at the scale of the Metropolis and the Highway [63]. Besides this, only one book, called Fast Forward Urbanism [64], uses the term Fast. Alternatively, rapid urbanism is slightly more used, but mostly pays attention to the negative aspects of fast growing cities in Africa [65] or the mega urban developments in China [66]. In this article Fast Urbanism is defined as a form of urbanism, which is, under pressure of economic growth, developed in a fast pace and generally executed as one Master plan. As examples of fast urbanism the urban developments in China [67] [68] and, at a more modest scale, the VINEX-neighbourhoods in the Netherlands [69]-[71] can be mentioned. These fast urban developments are designed on the basis of a clear calculated program. The number of houses for the increase in population determines this program and the Master plan is designed fulfilling these demands. Most of these new towns are located at the edges of existing urban conurbations and are realised in a short time frame. They are large in the sense of number of houses and area occupied. As long as the economy grows there is no disturbance in the production flow. One of the steady fast growing areas is Almere Buiten (Figure 3) in the Netherlands with, in the successful years, a production of around 3000 houses per year.

The space for Fast Urbanism is often found outside the city because this is easier and cheaper than to retrofit existing urban neighbourhoods. The land prices when land is bought of farmers, is much cheaper than an urban plot. Fast urbanism is successful in economic prosperity, though the long-term satisfaction can be doubted. Examples from Australia show that the new urban development at the fringes of large metropolises are home to more divorces, solitude and higher energy bills than people experience in the inner city or urban neighbourhoods close to the CBD [73] [74].

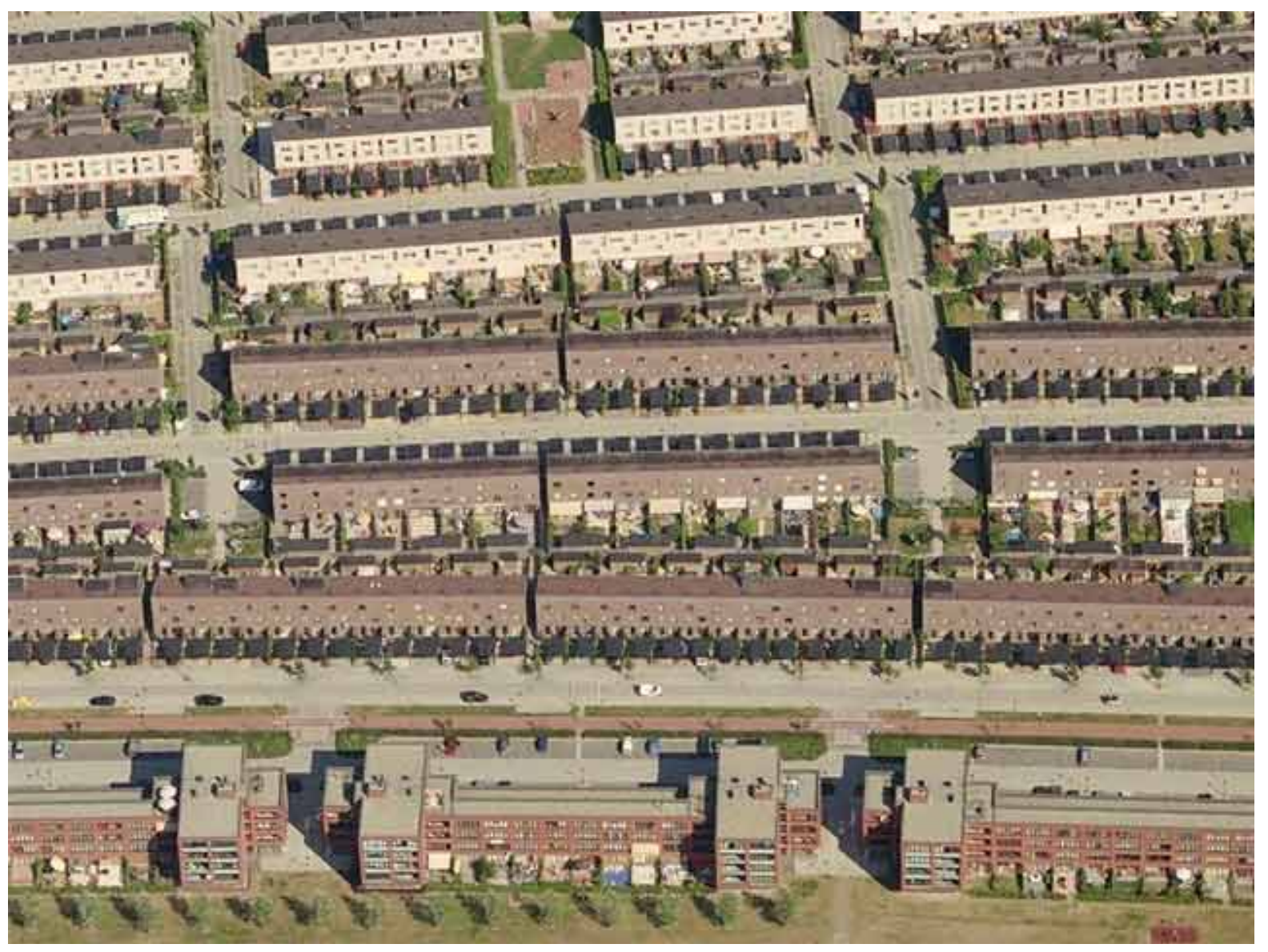

Figure 3. Almere Buiten [72]. 


\subsection{Slow Urbanism}

Slow Urbanism or Slow Urbanization [75] is identified as a type of urbanism [76]-[79], which emphasises the slow pace of urban development in areas or periods of economic stagnation. In this context there is extra attention in the urban design for ecology, urban food production, social cohesion and urban water management in the public space. It facilitates urban neighbourhood development and often offers the residents the possibility to give substance to his own lifestyle requirements. This increases the flexibility of the overall urban design, within which people are free to develop small and short-term changes (see for instance: [80]. Freedom of choice for the residents combined with smart investment strategies and new pride together shape sustainable developments in a slowly developing urban environment. Slow urbanism is often used as a strategy for retrofitting existing urban areas, where the pressure is lower and the need to plan for new housing or industrial areas is absent. Let the spaces emerge for Slow Urbanism.

\subsection{Suddenism}

When the city is suddenly confronted with serious impacts of a disaster, it becomes often visible that the city wasn't planned for these events. Knowing that these events will increasingly occur and the impacts tend to become more severe, the urban design should take these issues into account. However, the uncertainty in the type, magnitude and timing of these events makes them difficult to plan for. The urban design needs to anticipate something that is unprecedented and uncertain. This type of urbanism, suddenism, is defined as a way of urban design, which is capable of accommodating the spatial impacts of a (climatic) disaster through locating spatial areas at strategic places where water, fire or rocks or other elements can do no harm. These spaces are only temporarily required, but must be part of the urban fabric to prevent damage and losses. Suddenism is a new addition to the range of urban design approaches, which is needed because to date cities are hardly prepared for these kinds of events. In practice the urban design starts when the disaster is over and the rebuilding process starts. Examples of these processes can recently be witnessed after the Katrina hurricane in New Orleans [81] [82], Cyclone Yasi in Queensland [83], Hurricane Sandy in New York [84] [85], the Tsunami in Fukushima [86] [87], and typhoon Haiyan in the Philippines [88], amongst many others. Every time again, the rebuilding starts after the disaster has hit, instead of it being a process of urban design beforehand. Suddenism proposes to anticipate the sudden climate event and designs a city in which spaces are incorporated that could deal with the consequences of a disaster without hurting people and preventing damage.

\section{Three Urbanisms in One City?}

After distinguishing three types of urbanism for different problems in the city it is clear that each could enhance resilience of the city in its own way and according urban spaces need to be realised to accommodate each of the problem types. Every city has to deal with all three problem-types and apply the different design strategies in planning the city. These design strategies shouldn't be seen as separate approaches, but ideally must be integrated. This is not easy as both the periods when as the urban areas where the strategies must be applied are not congruent, but diverge. This implies that when a certain strategy might be useful for one area in a certain period, the same area requires another approach the next period. For true integration of the different types of urbanism, they need to be applied all at the same time. This is a pledge for designing three layers of urbanism simultaneously after which they can be integrated in one urban design. The programs for fast urbanism, and the spaces designed for slow urbanism and required for Suddenism then fit together in one design, providing solutions for every context the city might have to deal with in the future. Within areas designed under the Fast Urbanism paradigm spaces must be created for Slow Urbanism and Suddenism. The likely consequence of this approach is the city as a whole becomes less dense than current cities are developed. However, this requires further design research to draw definite conclusions. When the three urbanisms are integrated the paces of developing urban structures are also integrated.

\section{Conclusions}

In this article three urbanisms are introduced. The reason for making a distinction in urbanisms lies in the pace of change which cities are confronted with. Ideally, three types of urbanism are used simultaneously in the urban design process, in order to create spaces for problems of a shrinking city and the impacts of climate change. 
When each urbanism is designed as a separate layer and is integrated in one design afterwards, the urban patterns and structures needed from each of the perspectives can be accommodated in the integrated design.

The advantage of thinking in three urbanisms lies in the anticipative power. It is often the case that a city is designed in times of economic prosperity and the pressure to realise housing and industrial sites is large. In this period there is mostly no room to design for shrinkage or unprecedented climate problems. When the three layers are designed, at the same time, the spaces needed in the future can be anticipated from the beginning. This implies that land uses, which develop slowly over a longer period of time can be accommodated at all times, and the city deals with climate impacts before they occur, hence preventing the damage and losses resulting form it.

Finally, the urban design brings a larger spatial diversity. Fast urbanism brings a certain spatial typology as do slow urbanism and suddenism. When these typologies are developed in the same area the diversity of housing types, public spaces and other uses is enriched.

\section{References}

[1] UN (2014) World Urbanization Prospects. UN, New York.

[2] Keating, J. (2014) World on the Move. http://www.slate.com/blogs/the_world_/2014/04/02/world_on_the_move_five_years_of_global_migration_in_one_cha rt.html

[3] Abel, G.J. and Sander, N. (2014) Quantifying Global International Migration Flows. Science, 343, 1520-1522. http://dx.doi.org/10.1126/science.1248676

[4] Metcalfe, J. (2014) A Fascinating Visualization of World Migration. Where Are People Relocating from and Where Are They Heading? http://www.citylab.com/work/2014/04/new-visualization-world-migration-flows/8801/

[5] IPCC (2012) Summary for Policymakers. In: Field, C.B., Barros, V., Stocker, T.F., Qin, D., Dokken, D.J., Ebi, K.L., Mastrandrea, M.D., Mach, K.J., Plattner, G.-K., Allen, S.K., Tignor, M. and Midgley, P.M., Eds., Managing the Risks of Extreme Events and Disasters to Advance Climate Change Adaptation. A Special Report of Working Groups I and II of the Intergovernmental Panel on Climate Change, Cambridge University Press, Cambridge, 1-19.

[6] Hallegatte, S., Green, C., Nicholls, R.J. and Corfee-Morlot, J. (2013) Future Flood Losses in Major Coastal Cities. Nature Climate Change, 3, 802-806. http://dx.doi.org/10.1038/nclimate1979

[7] De Sherbinin, A., Schiller, A. and Pulsipher, A (2007) The Vulnerability of Global Cities to Climate Hazards. Environment \& Urbanization (IIED), 39, 39-64. http://dx.doi.org/10.1177/0956247807076725

[8] WWF (2009) Mega-Stress for Mega-Cities: A Climate Vulnerability Ranking of Major Coastal Cities in Asia. WWF, Gland.

[9] Nicholls, R.J. (1995) Coastal Megacities and Climate Change. GeoJournal, 37, 369-379. http://dx.doi.org/10.1007/BF00814018

[10] Haase, A., Bernt, M., Grossmann, K., Mykhnenko, V. and Rink, D. (2013) Varieties of Shrinkage in European Cities. European Urban and Regional Studies. http://dx.doi.org/10.1177/0969776413481985

[11] Rink, D., Haase, A., Bernt, M. and Großmann, K. (2010) Addressing Urban Shrinkage across Europe-Challenges and Prospects. Shrink Smart Research Brief No. 1, November 2010. Helmholtz Centre for Environmental Research-UFZ, Leipzig. https://shrinksmart.ufz.de/data/D9\%20Research\%20Brief\%20214223.pdf

[12] Rink, D., Couch, C., Haase, A., Krzysztofik, R., Nadolu, B. and Rumpel, P. (2014) The Governance of Urban Shrinkage in Cities of Post-Socialist Europe: Policies, Strategies and Actors. Urban Research and Practice, 7, 258-277. http://dx.doi.org/10.1080/17535069.2014.966511

[13] Platt, S. (2004) Causes of Urban Shrinkage: An Overview of European Cities. Proceedings of the COST CIRES Conference, Amsterdam, 16-18 February 2004.

[14] Pallagst, K. (2009) Shrinking Cities in the United States of America: Three Cases, Three Planning Stories. The Future of Shrinking Cities, 1, 81-88.

[15] Bontje, M. (2005) Facing the Challenge of Shrinking Cities in East Germany: The Case of Leipzig. Geo Journal, 61, 13-21. http://dx.doi.org/10.1007/sGEJO-004-0843-7

[16] Hollander, J. and Németh, J. (2011) The Bounds of Smart Decline: A Foundational Theory for Planning Shrinking Cities. Housing and Policy Debate, 21, 349-367. http://dx.doi.org/10.1080/10511482.2011.585164

[17] Wiechmann, T. and Pallagst, K.M. (2012) Urban Shrinkage in Germany and the USA: A Comparison of Transformation Patterns and Local Strategies. International Journal of Urban and Regional Research, 36, 261-280. http://dx.doi.org/10.1111/j.1468-2427.2011.01095.x 
[18] Müller, B. and Siedentop, S. (2015) Growth and Shrinkage in Germany—Trends, Perspectives and Challenges for Spatial Planning and Development. (C) 2015 Deutsches Institut für Urbanistik gGmbH. http://www.difu.de/print/6053

[19] Hollander, J.B., Pallagst, K., Schwarz, T. and Popper, F.J. (2009) Planning Shrinking Cities. Progress in Planning, 72 , 223-232.

[20] Sousa, S. and Pinho, P. (2015) Planning for Shrinkage: Paradox or Paradigm. European Planning Studies, $23,12-32$. http://dx.doi.org/10.1080/09654313.2013.820082

[21] Rink, D., Rumpel, P., Slach, O., Cortese, C., Violante, A., Bini, P.C., Haase, A. Mykhnenko, V., Nadolu, B., Couch, C. Cocks, M. and Krzystofik, R. (2012) Governance of Shrinkage-Lessons Learnt from Analysis for Urban Planning and Policy. Shrinking Smart D13, D14 and D, 14. https://www.ufz.de/export/data/400/39029_WP7_D13_14_15_FINAL_2.pdf

[22] Panagopoulos, T. and Barreira, A.P. (2012) Shrinkage Perceptions and Smart Growth Strategies for the Municipalities of Portugal. Built Environment, 38, 276-292. http://dx.doi.org/10.2148/benv.38.2.276

[23] Detroit Future City (2012) Detroit Strategic Framework Plan. Island Press, Detroit.

[24] Sjerps, M. (Red.) (2009) De nieuwe groei heet krimp. Een perspectief voor Parkstad Limburg. NICIS Institute, Den Haag.

[25] Provincie Groningen (2010) Van planning voor groei en planning met krimp Naar planning voor krimp. Naar een nieuwe planningsmethode die anticipeert op structurele bevolkingsdaling. Provincie Groningen, Groningen.

[26] Florentin, D. (2010) The "Perforated City:” Leipzig’s Model of Urban Shrinkage Management. Berkeley Planning Journal, 23, 83-110. https://escholarship.org/uc/item/97p1p1jx

[27] Bontje, M. (2005) Facing the Challenge of Shrinking Cities in East Germany: The Case of Leipzig. GeoJournal, 61, 13-21. http://dx.doi.org/10.1007/sGEJO-004-0843-7

[28] Oswalt, P. (2014) Shrinking Cities and Productive Urban Landscapes. In: Viljoen, A. and Bohn, K., Eds., Second Nature Urban Agriculture. Designing Productive Cities, Routledge, London and New York.

[29] Reverda, N. (2012) Krimp en vergrijzing: De noodzaak van sociale duurzaamheid. NEIMED, Heerlen.

[30] Ruimtevolk (2014) Nieuw elan voor krimpregio’s. http://bottomup.ruimtevolk.nl/2014/10/09/nieuw-elan-voor-krimpregios/

[31] Dagevos, H., De Bakker, E., Vogelzang, T., Meeusen, M., Bongers, R., Van den Brink, E., Baidenmann, J. and Sasburg, H. (2015) De kunst van verbinden. Pluriforme praktijkvoorbeelden binnen en buiten de agrifoodsector. LEI Wageningen UR, Wageningen.

[32] Aalvanger, A. and Breman, B. (2013) Een vruchtbaar initiatief. Lessen en ervaringen van Sint Jan Kloosterburen. Rapport 301, WUR, Wageningen.

[33] Schwartz, T. and Rugare, S., Eds. (2009) Pop-Up City. Kent State University, Cleveland Urban Design Collaborative, Cleveland.

[34] Müller, R. (2010) When Less Is More: Eastern German Project Provides Hope for Shrinking Cities. Spiegel Online International. http://www.spiegel.de/international/germany/when-less-is-more-eastern-german-project-provides-hope-for-shrinking-c ities-a-688152-2.html

[35] Arentsen, M. and Bellekom, S. (2014) Power to the People: Local Energy Initiatives as Seedbeds of Innovation? Energy, Sustainability and Society, 4, 2. http://dx.doi.org/10.1186/2192-0567-4-2

[36] Van der Schoor, T. and Scholtens, B. (2015) Power to the People: Local Community Initiatives and the Transition to Sustainable Energy. Renewable and Sustainable Energy Reviews, 43, 666-675. http://dx.doi.org/10.1016/j.rser.2014.10.089

[37] EC Boxtel (2015) Energie Cooperatie Boxtel. http://www.ecboxtel.nl

[38] Amelander Energie Cooperatie (2015) Amelander Energie cooperatie. www.amelandenergie.nl

[39] Bredase Energie Services (2015) BRES. http://bresbreda.nl/bres-aanpak/

[40] Sterk, E. and Specht, M. (2013) Sociaal ondernemerschap. In: Sterk, E., Specht, M. and Walraven, G., Red., Sociaal ondernemerschap in de participatiesamenleving: Van de brave naar de eigenwijze burger, Garant, Antwerpen, Apeldoorn, 26-48.

[41] Feenstra, G.W. (1997) Local Food Systems and Sustainable Communities. American Journal of Alternative Agriculture, 12, 28-36. http://dx.doi.org/10.1017/S0889189300007165

[42] OnsLand (2015) Groente van ons land. http://www.onsland.org

[43] Drechtstadsboer (2015) Wat doet Steunpunt Drechtstadsboer? 
http://www.drechtstadsboercooperatie.nl/index.php/stadslandbouw-missie-drecht-stadsboer-cooperatie/

[44] Grumbach, K. and Mold, J.W. (2009) A Health Care Cooperative Extension Service: Transforming Primary Care and Community Health. JAMA, 301, 2589-2591. http://dx.doi.org/10.1001/jama.2009.923

[45] Wijzelf Zorgcooperatie (2015) Wijzelf Zorgcooperatiue. www.wijzelf.nl

[46] Zorgcooperatie Hoogeloon (2015) Zorgcooperatie. http://www.zorgcooperatie.nl/?p=zorgcooperatie

[47] Walker, B., Holling, C.S., Carpenter, S.R. and Kinzig, A. (2004) Resilience, Adaptability and Transformability in Social-Economic Systems. Ecology and Society, 9, 5. http://www.ecologyandsociety.org/vol9/iss2/art5/

[48] Walker, B. and Salt, D. (2006) Resilience Thinking. Island Press, Washington DC.

[49] Newman, P.W., Birrell, R., Homes, D., Mathers, C., Newton, P., Oakley, G., O’Connor, A., Walker, B., Spessa, A. and Tait, D. (1996) Human Settlements. In: Taylor, R., Ed., State of the Environment, Department of Environment, Australian Government, Canberra, 1-57.

[50] Newman, P., Beatley, T. and Boyer, H. (2009) Resilient Cities, Responding to Peak Oil and Climate Change. Island Press, Washington DC.

[51] Holling, C.S. (2001) Understanding the Complexity of Economic, Ecological and Social Systems. Ecosystems, 4, 390405. http://dx.doi.org/10.1007/s10021-001-0101-5

[52] www.resalliance.org/index.php/adaptive_cycle.

[53] www.resalliance.org.

[54] www.kpmg.com/au/en/issuesandinsights/articlespublications/australia-report/pages/risk-landscape-2012.aspx.

[55] Defra (2012) The UK Climate Change Risk Assessment 2012. Evidence Report. (C Crown. Defra, with HR Wallingford, AMEC Environment \& Infrastructure UK Ltd, The Met Office, Collingwood Environmental Planning, Alexander Ballard Ltd, Paul Watkiss Associates and Metroeconomica, London.

[56] Peterson, G.D., Carpenter, S.R. and Brock, W.A. (2003) Uncertainty and the Management of Multistate Ecosystems: An Apparently Rational Route to Collapse. Ecology, 84, 1403-1411. http://dx.doi.org/10.1890/0012-9658(2003)084[1403:uatmom]2.0.c0;2

[57] Roggema, R. (2012) Swarm Planning: The Development of a Spatial Planning Methodology to Deal with Climate Adaptation. PhD Thesis, Delft University of Technology \& Wageningen University and Research Center, Delft.

[58] Pisano, U. (2012) Resilience and Sustainable Development: Theory of Resilience, Systems Thinking and Adaptive Governance. ESDN Quarterly Report No. 26, ESD, Vienna.

[59] Ostrom, E. (1999) Coping with the Tragedies of the Commons. Annual Review of Political Science, 2, 493-535. http://dx.doi.org/10.1146/annurev.polisci.2.1.493

[60] De Jong, T.M. (2007) Context Analysis. Architectural Annual. 010 Uitgevers, Rotterdam.

[61] De Jong, T.M. (2007) Operational Context Analysis. As a Part of Design Related Study and Research. Proceedings of the 3rd IASME/WSEAS International Conference on Energy, Environment, Ecosystems and Sustainable Development, Agios Nikolaos, 24-26 July 2007, 281-291.

[62] De Jong, T.M. (2010) The Role of Art in Science. METU JFA, 27, 23-44. http://dx.doi.org/10.4305/METU.JFA.2010.1.2

[63] Payton, N.I. (2013) The Metropolis versus the City. In: Duany, A. and Talen, E., Eds., Landscape Urbanism and Its Discontents: Dissimulating the Sustainable City, New Society Publishers, Gabriola Island.

[64] Cuff, D. and Sherman, R. (2011) Fast-Forward Urbanism: Rethinking Architecture’s Engagement with the City. Princeton Architectural Press, New York.

[65] Young, A. (2014) No Pain, No Gain? Rapid Urban Growth and Urbanism in Addis Ababa. http://www.urbanafrica.net/urban-voices/pain-gain-rapid-urban-growth-urbanism-addis-ababa/

[66] Herrle, P., Fokdal, J. and Ipsen, D. (2014) Beyond Urbanism: Urban(izing) Villages and the Mega-Urban Landscape in the Pearl River Delta in China (HABITAT-INTERNATIONAL: Schriften zur internationalen Stadtentwicklung). LIT Verlag, Zürich/Berlin.

[67] Ye, A.G.O. and Wu, F. (1996) The New Land Development Process and Urban Development in Chinese Cities. International Journal of Urban and Regional Research, 20, 330-353. http://dx.doi.org/10.1111/j.1468-2427.1996.tb00319.x

[68] Chuang-Lin, F.A.N.G. (2009) The Urbanization and Urban Development in China after the Reform and Opening-Up. Economic Geography, 29, 19-25.

[69] Boeijenga, J., Mensink, J. and Grootens, J. (2008) Vinex Atlas. Uitgeverij 010, Rotterdam.

[70] Galle, M., Modderman, E., Galle, M.M.A. and Modderman, E.J.E. (1997) VINEX: National Spatial Planning Policy in the Netherlands during the Nineties. Netherlands Journal of Housing and the Built Environment, 12, 9-35. 
http://dx.doi.org/10.1007/BF02502621

[71] Zonneveld, W. and Nadin, V. (2015) Wil Zonneveld, Vincent Nadin—Netherlands. disP—The Planning Review, 51, 58-59. http://dx.doi.org/10.1080/02513625.2015.1038067

[72] http://www.davroadvies.nl/woonruimte/almere/ruime-eengezinswoning-te-huur-almere-buiten.

[73] Dodson, J. and Sipe, N. (2006) Shocking the Suburbs: Urban Location, Housing Debt and Oil Vulnerability in the Australian City. Urban Research Program, Research Paper 8, Griffith University, Brisbane.

[74] Dodson, J. and Sipe, N. (2008) Unsettling Suburbia: The New Landscape of Oil and Mortgage Vulnerability in Australian Cities. Urban Research Program, Research Paper 17, Griffith University, Brisbane.

[75] Dogrusoy, I.T. and Dalgakiran, A. (2011) An Alternative Approach in Sustainable Planning: Slow Urbanism. Archnet-IJAR, International Journal of Architectural Research, 5, 127-142.

[76] Hoornweg, D. (2013) Hey Cities Slow Down. http://blogs.worldbank.org/sustainablecities/hey-cities-slow-down

[77] Swen, H. and Hoogendoorn, J. (2011) Slow Urbanism als antwoord op de crisis. http://ruimtevolk.nl/2011/01/12/gebiedsontwikkeling-zaanij-kent-geen-eindbeeld/

[78] Blackson, H. (2012) The New Incrementalism. http://bettercities.net/news-opinion/blogs/howard-blackson/19116/new-incrementalism

[79] Knox, P.L. (2006) Creating Ordinary Places: Slow Cities in a Fast World. Journal of Urban Design, 10, 1-11. http://dx.doi.org/10.1080/13574800500062221

[80] http://www.kaw.nl/project/slow-urbanism-fast-architecture-2/.

[81] Kates, R.W., Colten, C.E., Laska, S. and Leatherman, S.P. (2006) Reconstruction of New Orleans after Hurricane Katrina: A Research Perspective. Proceedings of the National Academy of Sciences of the United States of America, 103, 14653-14660. http://dx.doi.org/10.1073/pnas.0605726103

[82] Olshansky, R.B. (2006) Planning after Hurricane Katrina. Journal of the American Planning Association, 72, 147-153. http://dx.doi.org/10.1080/01944360608976735

[83] Queensland Reconstruction Authority (2011) Rebuilding a Stronger, More Resilient Queensland. Queensland Government, Brisbane.

[84] Hurricane Sandy Reconstruction Task Force (2013) Hurricane Sandy Rebuilding Strategy. US Department of Housing and Urban Development, Washington DC.

[85] Kuehn, B.M. (2013) Rebuilding after Disaster: Recovering Research Takes Time, Planning. JAMA, 309, 123-124. http://dx.doi.org/10.1001/jama.2012.97307

[86] Godzik, M. (2013) Rebuilding Housing in Japan's Tsunami-Hit Towns and Cities. International Journal of Housing Policy, 13, 433-445. http://dx.doi.org/10.1080/14616718.2013.852301

[87] Mochizuki, J. (2014) Decision-Making, Policy Choices and Community Rebuilding after the Tohoku Disaster. IDRiM Journal, 4, 11-26.

[88] Milman, O. (2015) Life in the Philippines: Preparing for the Next Typhoon Haiyan. http://www.theguardian.com/environment/2015/mar/25/life-in-the-philippines-preparing-for-the-next-typhoon-haiyan 